\title{
Enhancement of visibility of structures in marly chalk: modification of the Bushinsky oil technique
}

\author{
RICHARD G. BROMLEY
}

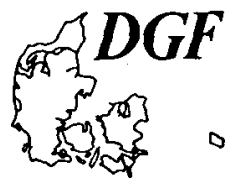

\begin{abstract}
Bromley, R. G.: Enhancement of visibility of structure in marly chalk: modification of the Bushinsky oil technique. Bull. geol. Soc. Denmark, vol. 29, p. 111-118, Copenhagen, January 19th, 1981. https://doi.org/10.37570/bgsd-1980-29-06

The outwardly monotonous appearance of white chalk is deceptive, yet the several techniques that have been applied to enhance visibility of hidden structures have all had limited success. A technique published by Bushinsky in 1947 produces excellent results with chalks containing a trace of clay minerals. Bushin-sky's technique involves incomplete impregnation of chalk samples with light machine oil, but still better results were obtained by lightly brushing oil onto smoothed surfaces of chalk. The heightened contrast of the structures thereby achieved can be still further increased photographically by use of high contrast line copy film. The results obtained are compared with those using fluorescence by ultraviolet radiation or by merely wetting the chalk. Both contrast and resolution are better with oil than with water or ultraviolet.
\end{abstract}

R. G. Bromley, Institut for historisk Geologi og Palcontologi, Øster Voldgade 10, DK-1350 Copenhagen K, Denmark, February 8th, 1980.

Limestones are notoriously reticent about revealing internal structures. Some success in improvement in visibility can be had through the use of various techniques; Thiede \& Larsen (1971), for example, made $\mathrm{X}$-radiographs of thin slabs and Bockelie (1973) photographed polished surfaces under alcohol, glycerol or oil.

Visibility of structures in chalks is particularly poor owing to their homogeneity and purity. Furthermore, their extremely weak lithification and high permeability render them unsuited to several of the techniques developed for lithified limestones. Attempts to ease this problem have not met with great success.

Steinich (1967) had a measure of success in revealing trace fossils, lamination and fracturing in white chalk by impregnating with the hardener Epilox, but the technique is time-consuming and expensive, and few workers have made further use of it.

Thiede \& Larsen (1970 and 1971) made $\mathrm{X}$-radiographs of soft chalk, but the images had low resolution (1970, fig. 2; 1971, figs 7-9) and this techniques also failed to gain popularity.

Greater success has been achieved with the ultraviolet technique, originally applied to the detection of phosphates in chalks (Zumpe 1964). Application of this technique to white chalk revealed many hidden structures; particularly trace fossils (Bromley 1965) and permitted them to be photographed (Håkansson, Bromley \& Perch-Nielsen 1974, figs 5-6; Farrow 1975, fig. 2).

Staining with organic stains such as methylene blue and malachite green has also been used by some workers with varying success in pure chalks (e.g. Bromley 1967: 168, 182).

As early as 1947, however, Bushinsky published yet another method for'the enhancement of structures in marly chalks, involving incomplete impregnation with oil. My early attempts with this technique on very pure English Turonian to Santonian white chalks were unsuccessful, and I abandoned the method in favour of ultraviolet. Recently, Bushinsky \& Shumenko (1979) republished the oil technique and this stimulated me to make further experiments, this time using marly Danish Maastrichtian chalk. Results were now spectacularly successful; repetition of the original experiments showed that it had been the composition of the English chalk and not the method that had defeated my earlier attempt.

The Busansky oil technique

The essential features of Busansky's technique are as follows:

1. The surface of the dried chalk sample is smoothed. 


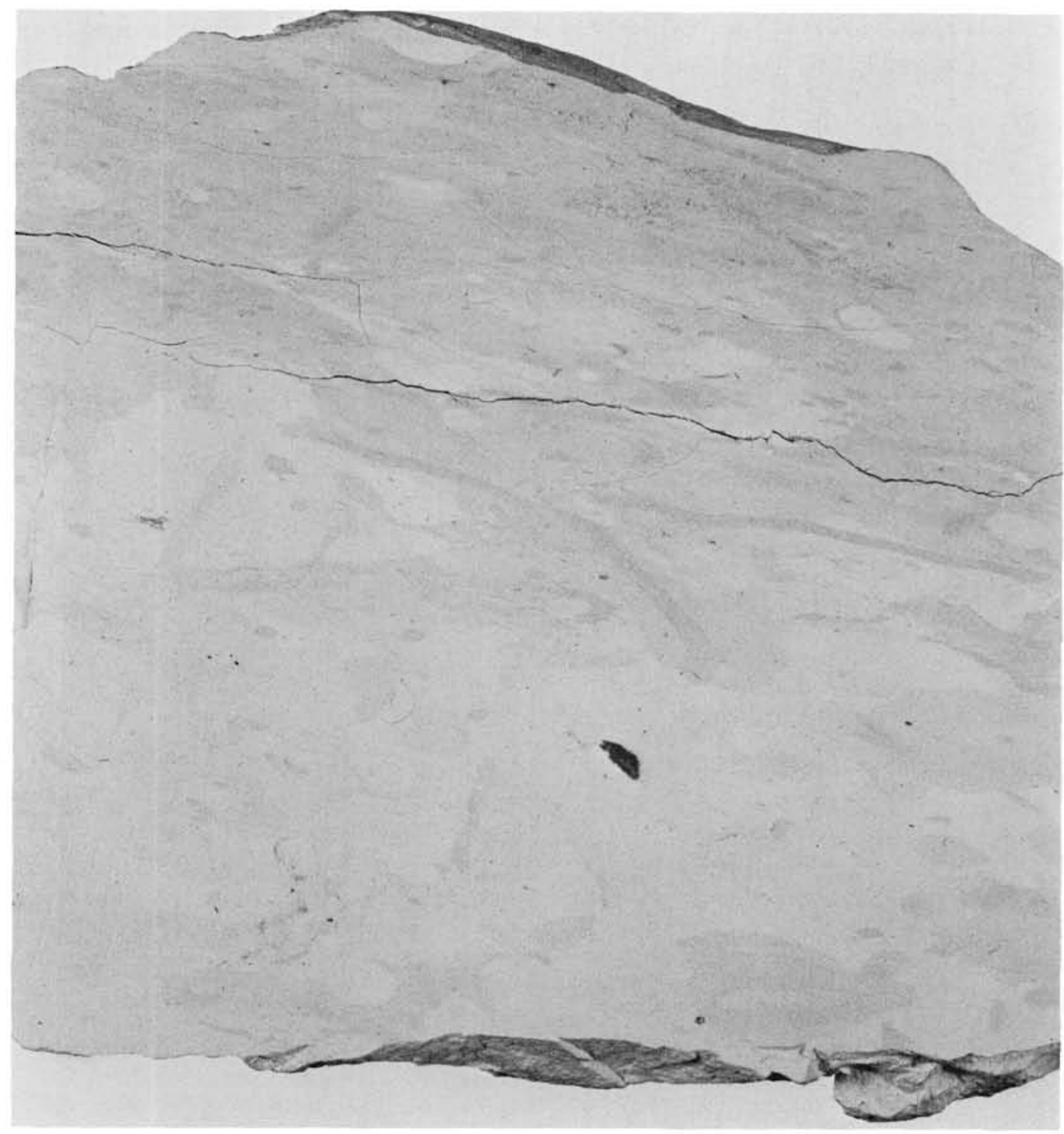

Fig. 1. Vertical section of marly chalk photographed dry. The black body is a limonitized pyrite concretion. The cracks appeared when the specimen was wetted in preparation for fig. $2 . \times 1$.

2. The sample is placed in oil for 10 minutes to two hours, depending on the viscocity of the oil and porosity of the rock.

3. About 10 minutes to an hour after removal of the sample from the oil, the colour contrast of the structures increases to a maximum, and remains constant more or less permanently.

4. Oversaturation of the rock gives poor results, but some improvement may then be achieved by heating the sample, which drives excess oil to the surface, where it may be removed with a tissue.

5. Experimenting with many oils led Bushinsky to the result that pale-coloured light machine oil produced the most acceptable results.

\section{Modified technique}

My own experiments, using Maastrichtian marly chalk from the base of bed M 12 from the quarry Dania, Mariager, Denmark (see Håkansson \& 


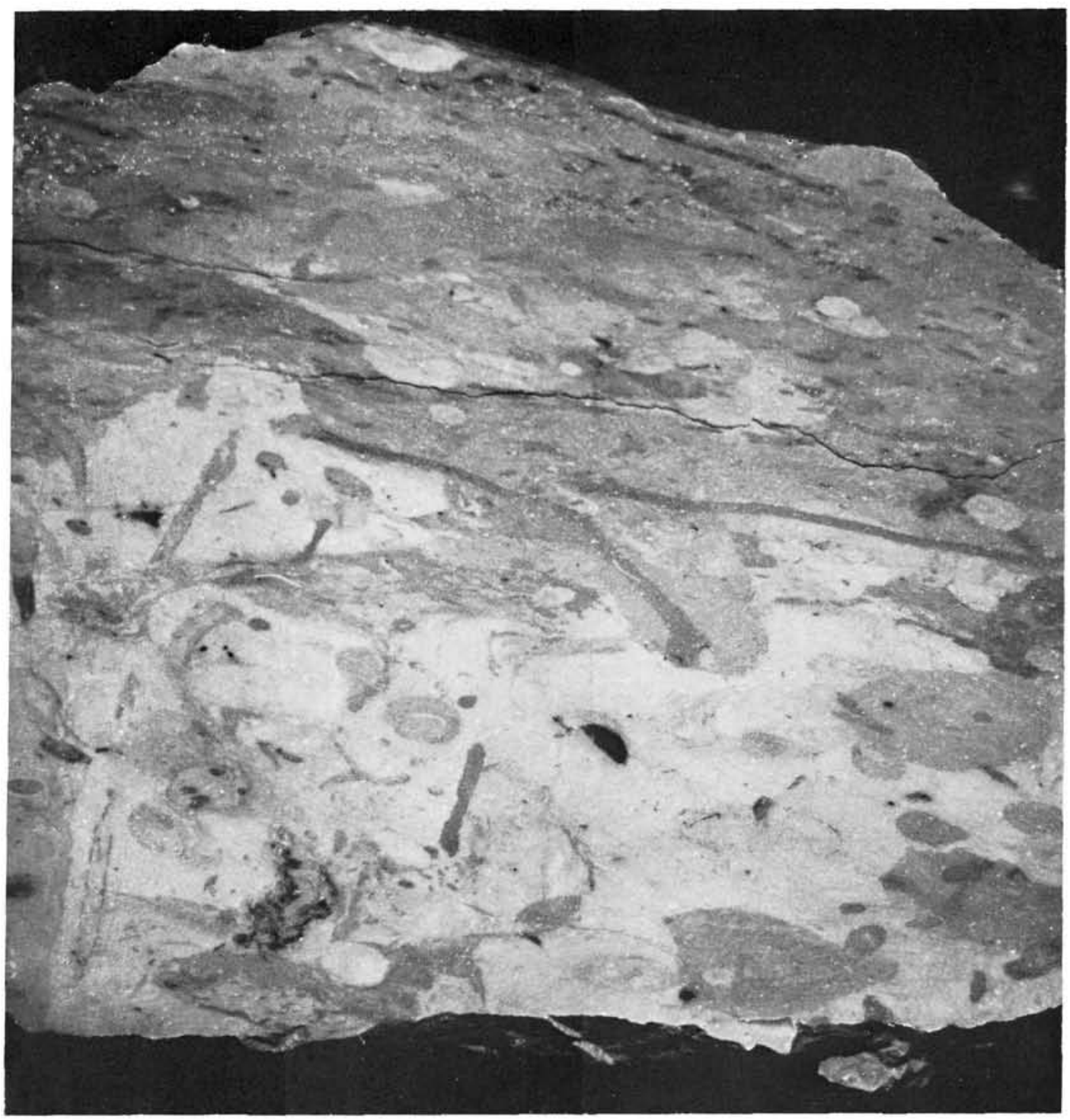

Fig. 2. As fig. 1, but photographed after removal from water in which the sample was immersed for some minutes. $\times 1$.

Hansen 1979: 187), reproduced Bushinsky's results. It was soon discovered, however, that greater contrast and even finer resolution could be attained by merely painting a thin layer of oil on the surface of the chalk and letting this soak in. This produced only a temporary image, but gave ample time, nevertheless, for photography and study. Contrast could be further increased, revealing even greater detail, by the use of high contrast line copy film (cf. Howell 1977). Indeed, by printing from this on hard paper, too great a contrast was achieved from a sample which, in dry condition, was almost pure white!

Essential features of the modified technique are as follows:

1. A surface is best cut in soft, marly chalk with a hand saw. The surface is then smoothed with a knife.

2. Ensuring that the rock is dry, oil is applied 


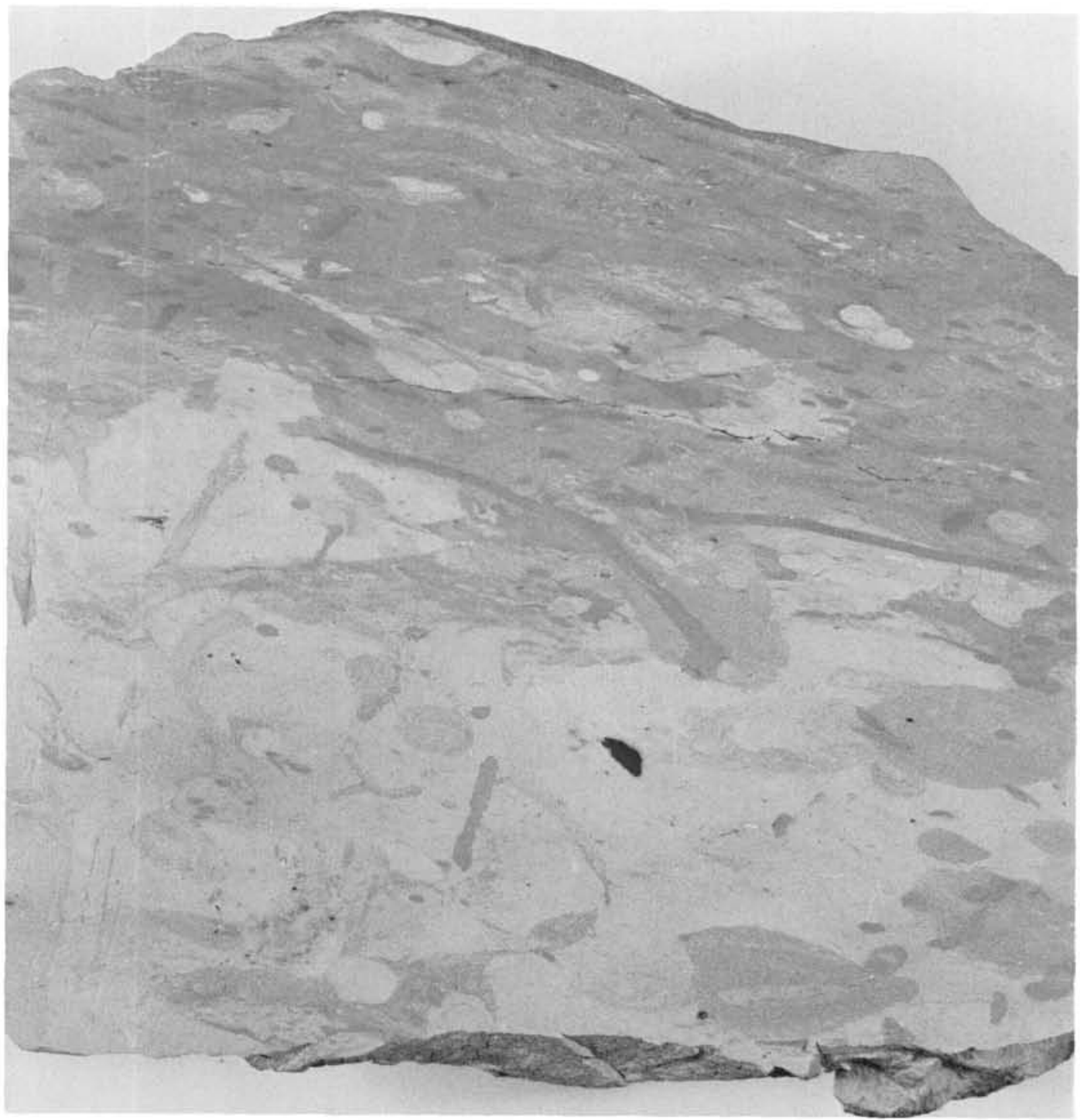

Fig. 3. As fig. 1, but photographed dry by ultraviolet radiation using a Wratten $2 \mathrm{E}$ total UV filter. The UV source was an Osira 80 watt mercury bulb having a Wood's Glass envelope, transmitting $95 \% 3650 \AA . \times 1$.

evenly to the surface, using a brush or roller. Evenness of application is important if the surface is to be photographed.

3. The surface immediately takes on the colour of the oil. Almost at once, however, structures begin to become visible, rather in the manner that an image gradually appears on photographic paper in the developing bath. During the next 5 to 15 minutes, the colour steadily fades while the contrast of the image gradually increases, until an optimum visibility is reached. Colour continues to fade, however, and after approximately an hour visibility is noticeably reduced. Contrast, however, still appears to increase and photographs taken at this late stage produce high resolution.

4. After several hours or days the sample returns (almost) to its original state. The effect can be rejuvenated, however, by application of a new oil film. The treatment can be repeated numerous times, but each time the colour is a shade darker and the contrast a trace lower. 


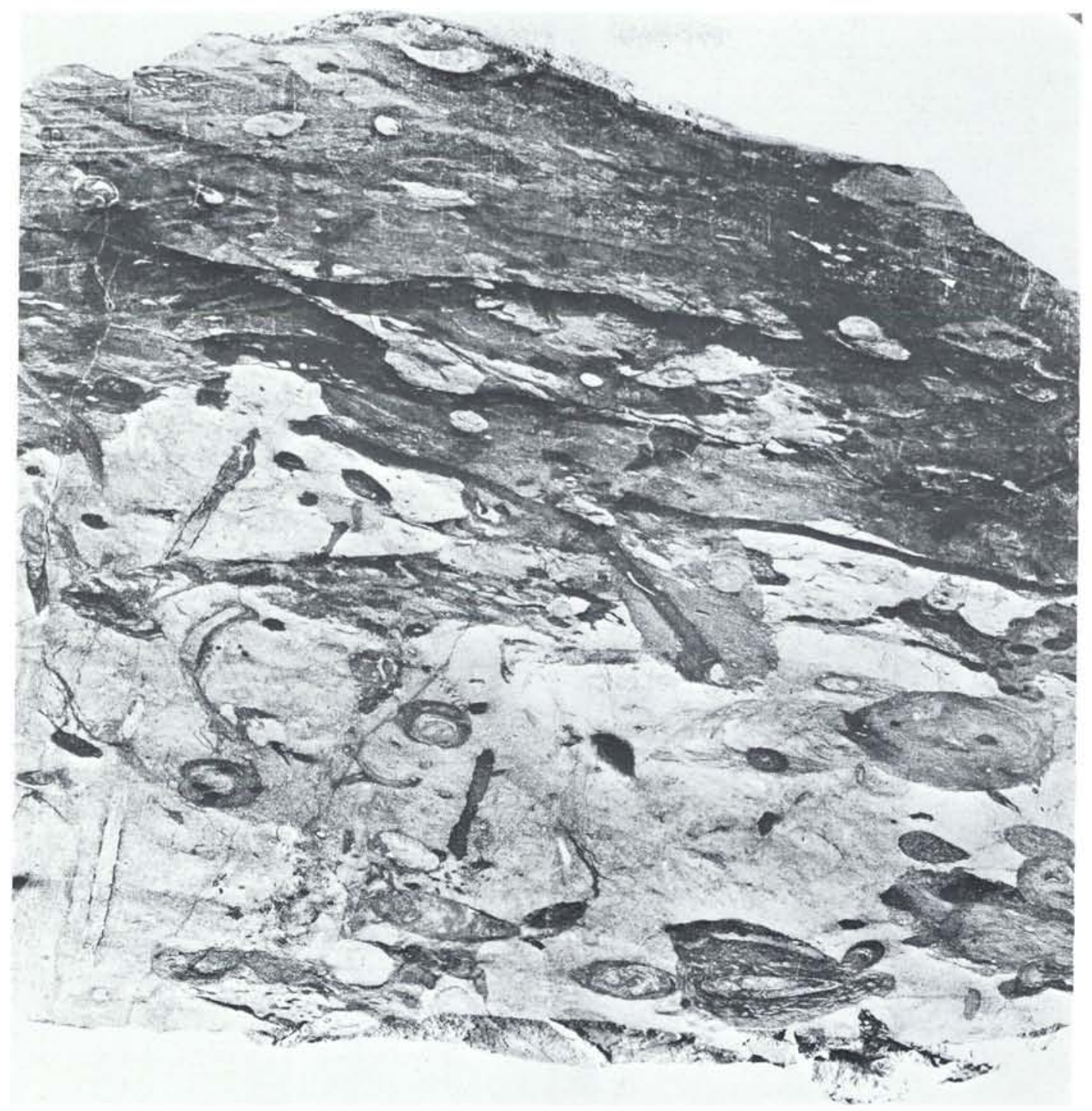

Fig. 4. As fig. 1, but painted with multi-purpose household oil and photographed on Fujilith line copy film at optimum visibility. Contact printed on normal (grade 2 ) paper. $\times 1$.

Ultimately the sample reaches the stage of saturation produced by Bushinsky's technique and the structures are permanently visible, albeit with relatively reduced contrast.

Results

Variable contingencies

Several types of oils were used. It was found that the paler the colour of the oil, the better the contrast it developed. Light machine oil and multipurpose household oil were found to be ideal.
More viscous oils take longer to develop optimum visibility but this stage lasts correspondingly longer before fading impairs visibility. The viscosity of the oil may be greatly reduced by admixture of petrol; the process is then greatly speeded up, allowing an image to 'flash up' rapidly, and in this way many samples of chalk can be tested quickly in order to select those worthy of closer study.

Varying permeability in different chalks also affects the time aspect of the technique. Highly 


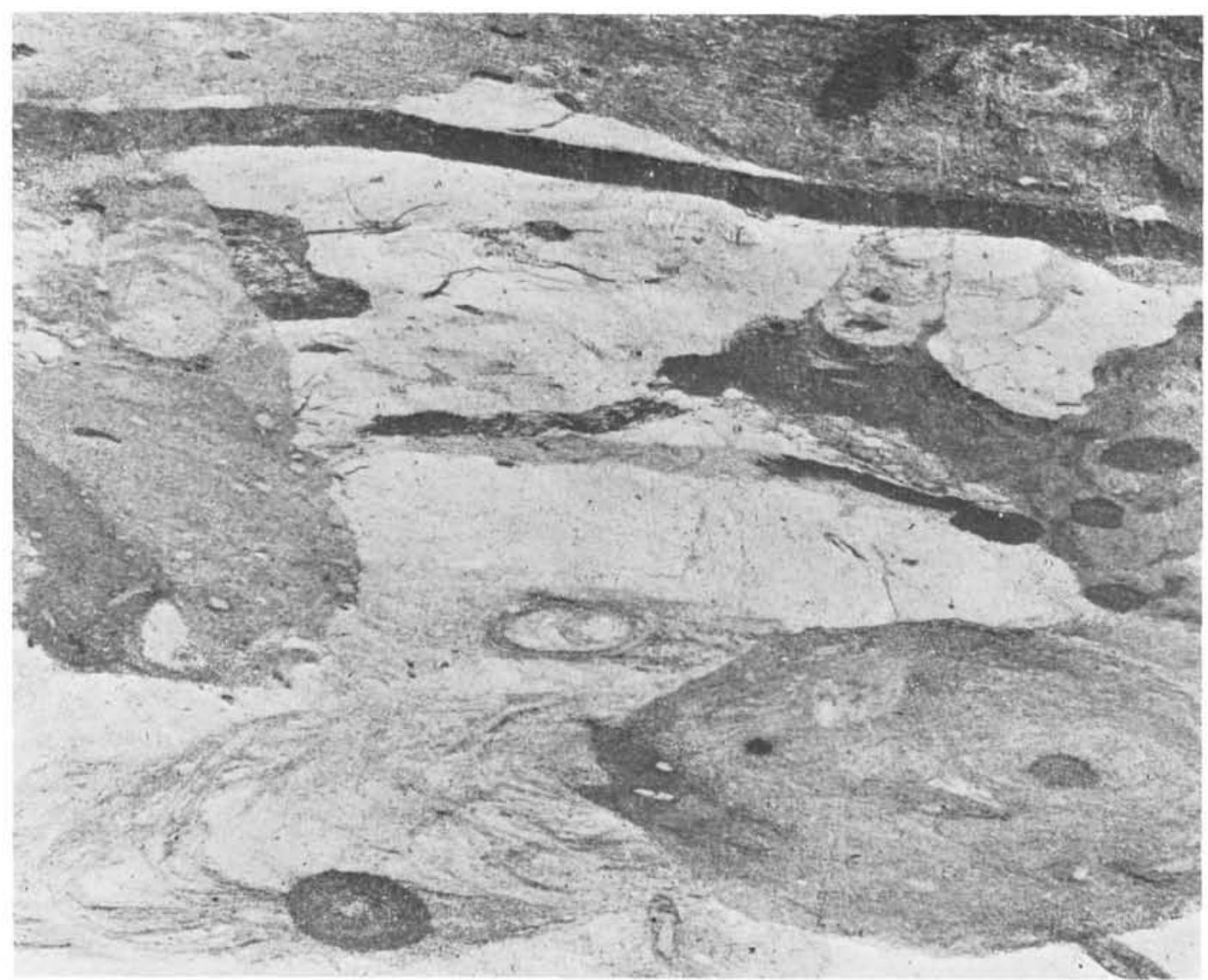

Fig. 5. Detail of fig. 4 from same negative, $\times 3$. Structures are visible that are at best merely pale shadows in fig. 2 .

permeable samples react more rapidly than tighter ones.

An important factor is the clay content of the chalk. Extremely pure, clay-free chalks yield poor results, though even here, results with oil are superior to those using other techniques. So far, the best results have been obtained in soft, fine-grained chalks containing about $1-3$ percent clay minerals.

\section{Comparison of techniques}

In order to compare the results obtained by oil with those by other techniques, a sample of chalk from the above locality and horizon was photographed dry (fig. 1), wet (fig. 2), fluorescing in ultraviolet (fig. 3) and with the modified oil method (fig. 4).

It was seen that the same structures were rendered visible by water as with ultraviolet, whereas these were not identical with those revealed by oil. Furthermore, not only did some structures emerge with oil that remained invisible with water or UV, but the resolution achieved with oil was markedly higher (fig. 5).

The finest detail can be seen by observing the high contrast negative, having an image $\times 1$ to $\times$ 2 of the original specimen, under a binocular microscope by transmitted light at low magnifications. The chalk then appears to be pelleted, consisting of rounded bodies of approximately $0.1 \mathrm{~mm}$, but somewhat variable in size. (The grain of the film is at least one order of magnitude smaller than this). The heterogeneous structure can also be seen, less clearly, in greatly enlarged prints made from such negatives (fig. 6). The bodies vary greatly in contrast, some being paler and some darker than background, and they are most distinct in burrow fills. It is tempting to interpret these structures as faecal pellets; there is, after all, ample evidence of the activity of de- 


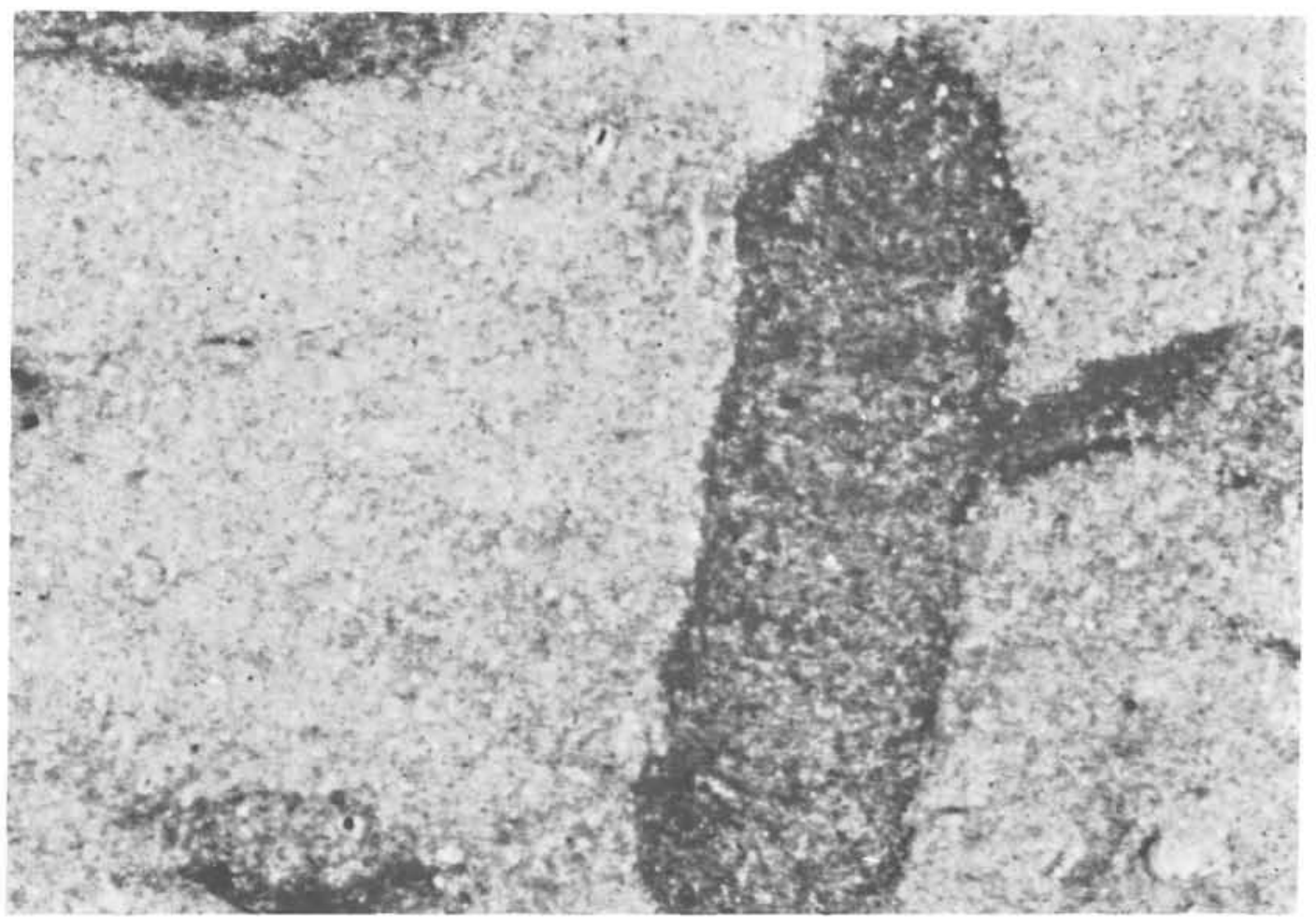

Fig. 6. Detail of fig. 4 from same negative, $\times 14$. The well-defined, dark, vertical object below middle of fig. 2 is seen with oil to have a retrusive spreite structure, and to consist of pellets of the order of size of $0.1 \mathrm{~mm}$. The surrounding chalk also gives the impression of being pelleted.

posit-feeding organisms in the form of abundant fodinichnia. This interpretation is difficult to prove, however, for the pellets have not been seen either in thin sections or in SEM pictures of Danish chalks.

The new method has another advantage over wetting. Marly chalk that has been allowed to dry out, tends to crack and disintegrate when rewetted, presumably owing to expansion of the clay minerals. Repeated treatment with oil, however, causes no such cracking.

\section{Conclusions}

The painting of oil onto dry samples or marly chalk produced results far superior to those obtained by other techniques. Normally invisible or poorly visible structures are rendered clear and distinct, and photography on high contrast film and paper allows the documentation of hitherto unseen, fine detail. The technique is simple and speedy, and requires no special equipment; the materials are inexpensive and readily available. Studies in chalk sedimentology and especially ichnology should receive considerable impetus from the application of the Bushinsky oil technique.

\section{Dansk sammendrag}

Skrivekridts tilsyneladende ensartede udseende er et bedrag. Mange teknikker har været anvendt med begrænset succes til at bringe skjulte strukturer frem. Bushinsky (1947) anbefalede en ufuldstændig imprægnering med let maskinolie af kridtprøver med et ringe indhold af lermineraler. Bedre resultater opnás ved let pábørstning af olie på glatte skrivekridtflader; dette forhøjer kontrasten mellem strukturer. Kontrasten kan yderligere styrkes via affotografering med repro-film. Resultaterne sammenlignes med dem opnået ved ultraviolet bestråling eller blot ved gennemvædning af kridtet med vand. Både kontrast og opløsning af strukturerne er bedre ved anvendelsen af olie end ved vand og ultraviolet. 


\section{References}

Bockelie, T. G. 1973: A method of displaying sedimentary structures in micritic limestones. J. sed. Petrol. 43: 537-539.

Bromley, R. G. 1965: Studies in the lithology and conditions of sedimentation of the Chalk Rock and comparable horizons. Unpubl. Ph. D. Thesis, Univ. London, 355 pp.

Bromley, R. G. 1967: Some observations on burrows of thalassinidean Crustacea in chalk hardgrounds. Quart. J. geol. Soc. London 123: 157-182.

Bushinsky, G. I. 1947: Textures and structures of Cretaceous chalk and flints (Russian with English summary). Bull. Soc. Natural., Moscow, N. S. 52 (Geol.), 22: 37-43.

Bushinsky, G. I. \& Shumenko, S. I. 1979: Writing chalk and its origin (Russian). Lith. Min. Deposits, Acad. Sci. U.S.S.R. 1979, (2): 37-54.
Farrow, G. E. 1975: Techniques for the study of fossil and recent traces. In Frey, R. W. (editor): The study of trace fossils. Springer: New York, 537-554.

Håkansson, E., Bromley, R. \& Perch-Nielsen, K. 1974: Maastrichtian chalk of north-west Europe - a pelagic shelf sediment. Spec. Publs int. Ass. Sediment. 1: 211-233.

Håkansson, E. \& Hansen, J. M. 1979: Guide to Maastrichtian and Danian boundary strata in Jylland. In Birkelund, T. \& Bromley, R. G. (editors): Cretaceous-Tertiary Boundary Events Symposium I: 171-188. Copenhagen.

Howell, J. 1977: Photography of low-contrast fossils. J. Paleont. 51, 419-420.

Thiede, J. \& Larsen, G. 1970: Zur Herstellung von Radiographien feinkörniger Kalke. $N$. Jb. Geol. Paläont., $M h$. 12: 723-735.

Thiede, J. \& Larsen, G. 1971: Radiographies of consolidated calcareous sediments from Denmark. Bull. geol. Soc. Denmark 20: 307-328.

Zumpe, H. H. 1964: The detection of phosphatization in calcareous sediments - a fluorescence method. J. sed. Petrol. 34: 691-692. 